\title{
Implementasi Peraturan Daerah Sulawesi Utara No.1 Tahun 2014 Pasal 55 Ayat 1 mengenai Kawasan Pariwisata Alam (Studi Kasus pada Bantaran Danau Tondano
}

\author{
Sisca Kairupan*, Marthinus Mandagi a, ${ }^{*}$ \\ ab Universitas Negeri Manado, Prodi Ilmu Administrasi Negara, Manado, Indonesia \\ ${ }^{1}$ siscakairupan@unima.ac.id *; ${ }^{2}$ marthinusmandagi@unima.ac.id ;
}

IN F O A R T I K E L

Key word:

Tourism Management,

Implementation,

Community Participation

\section{A B S T R A C T}

The objectives of this study are: 1) To describe and analyze the management in accordance with the North Sulawesi Regional Regulation Number 1 of 2014 Article 55 Paragraph 3 concerning Nature Tourism Areas, in the management of tourism on the Lake Tondano Bank and its contribution to the local community; 2) Describe and analyze the factors that influence tourism management in the Lake Tondano area, Minahasa Regency for the benefit of the local community. This research uses descriptive qualitative method and naturalistic paradigm. The result of this research is that the implementation of North Sulawesi Regional Regulation No. 1 of 2014 Article 55 Paragraph 3 regarding Natural Tourism Areas has not been implemented properly in terms of inadequate accommodation, facilities, infrastructure and utilization of natural tourism potential that has not been optimal but in its development Bantaran Lake Tondano is very developed, seen from its potential including the condition of natural stars in this area which has beautiful natural panoramas, cool air, and clear water.

\section{INTISARI}

\section{Kata kunci:}

Pengelolaan Pariwisata,

Implementasi,

Partisipasi Masyarakat.

\begin{abstract}
Tujuan dari penelitian ini adalah: 1) Mendeskripsikan dan menganalisis pengelolaan sesuai dengan Peraturan Daerah Sulawesi Utara Nomor 1 Tahun 2014 Pasal 55 Ayat 3 tentang Kawasan Wisata Alam, dalam pengelolaan pariwisata di Bantaran Danau Tondano dan kontribusinya kepada masyarakat setempat; 2) Mendeskripsikan dan menganalisis faktor-faktor yang mempengaruhi pengelolaan pariwisata di kawasan Danau Tondano Kabupaten Minahasa untuk kepentingan masyarakat setempat. Penelitian ini menggunakan metode kualitatif deskriptif dan paradigma naturalistik. Hasil dari penelitian ini adalah Implementasi Peraturan Daerah Sulawesi Utara No.1 Tahun 2014 Pasal 55 Ayat 3 mengenai Kawasan Pariwisata Alam belum terlaksana dengan baik dilihat dari akomodasi, fasilitas, sarana, prasarana kurang memadai dan pemanfaatan potensi wisata alam yang belum optimal namun dalam pengembangannya Bantaran Danau Tondano sangat bisa dikembangkan dilihat dari potensi tersebut meliputi kondisi bintang alam pada kawasan ini yang memiliki keindahan panorama alam, udara yangsejuk, dan kejernian air.
\end{abstract}




\section{Pendahuluan}

\subsection{Latar Belakang dan Permasalahan}

Sebagai modal dasar pengembangan pariwisata yaitu alam dan budaya, meliputi alam dengan segala bentuk dan wujudnya berupa pemandangan alam, panorama, pegunungan, hutan, pantai dan lain sebagainya. Sedangkan kebudayaan berfungsi sebagai kebudayaan di bidang kebudayaan, seperti kehidupan masyarakat, kesenian, peninggalan sejarah, nilainilai adat, museum, arkeologi sastra. Kedua potensi tersebut memiliki kekuatan dan nilai masing-masing dalam upaya menempatkan keunggulan tersebut sebagai bagian penting dalam pengembangan pariwisata.

Pariwisata merupakan salah satu aset yang dapat dikembangkan oleh suatu daerah / daerah guna meningkatkan kunjungan wisatawan baik domestik maupun mancanegara. Peningkatan kunjungan wisatawan berdampak positif terhadap pertumbuhan ekonomi masyarakat baik di sekitar lokasi wisata maupun kawasan secara keseluruhan. Meningkatnya pertumbuhan ekonomi masyarakat dan daerah juga akan berdampak positif pada peningkatan Pendapatan Asli Daerah (PAD) yang dapat mendukung pembangunan di berbagai sektor dan meningkatkan kesejahteraan masyarakat [1].

Potensi sumberdaya internal memiliki arti, kekuatan dan karakter tersendiri dalam mendukung pengembangan pariwisata. Salah satu sumber daya alam yang dapat memberikan pendorong bagi tumbuh kembangnya pariwisata adalah sumber daya berupa danau. Potensi danau sebagai objek wisata memiliki karakter tersendiri. Danauc merupakan suatu tempat dimana perpaduan antara ketersediaan air dengan keindahan wujud dalam bentuk yang indah dan menarik serta bernuansa alam dimana air berperan penting dalam memberikan kehidupan pada sekitarnya. Danau merupakan potensi yang dapat dikembangkan sebagai obyek dan daya tarik wisata. Jika dilihat secara fungsional, danau berfungsi sebagai empat tempat penampungan air atau menampung air dari mata air dan mempunyai fungsi yang dapat memelihara hidrologi, selain itu danau juga dikaitkan sebagai fungsi irigasi dimana fungsi air di wilayah tertentu digunakan sebagai pemenuhannya. air untuk irigasi, elektrifikasi dan pemenuhan kebutuhan air. orang lain untuk masyarakat [2].

Keberadaan situ / danau / waduk dapat dikembangkan sebagai Pariwisata danau dalam pengembangannya perlu memperhatikan beberapa kriteria pengembangan Pariwisata danau seperti :

1. Mewujudkan kesadaran wisatawan tentang konservasi sumber daya alam melalui pemanfaatan sumber daya pariwisata secara berkelanjutan dan pencegahan dampak negatif lingkungan.

2. Menciptakan rasa bangga masyarakat sekitar terhadap lokasi yang dimilikinya dengan menyediakan berbagai fasilitas yang sesuai dengan karakter alam danau / waduk.

3. Mendorong partisipasi masyarakat lokal untuk mengembangkan kemampuan mengelola usaha pariwisata.

4. Memberdayakan masyarakat untuk mengembangkan kreativitas terkait penyediaan berbagai kebutuhan wisata seperti oleh-oleh, khas daerah, bisnis transportasi. [2].

Di samping kriteria sebagaimana dijelaskan di atas, dalam hal pengembangan Pariwisata danau perlu memperhatikan kriteria fisik yang harus jadi landasan dalam pengembangannya. Kriteria dimaksud meliputi;

1. Penyusunan peta pembangunan dan rencana penyediaan infrastruktur, dimana jalur dalam kawasan danau merupakan jalan yang memiliki kegunaan yang cukup tinggi, karena pengunjung yang memasuki Wisata Danau tidak diperkenankan membawa transportasi dalam bentuk apapun dengan peta lokasi sebagai pedoman yang berfungsi penting dan dapat mengubah pola sikap dan cara pengunjung selama berada di lokasi tempat rekreasi tersebut.

2. Penetapan kegiatan pembangunan infrastruktur pendukung wisata danau. Penyediaan infrastruktur ini meliputi jalan menuju kawasan, infrastruktur air bersih, listrik, telekomunikasi, kesehatan dan lain-lain. Panjang jalan perlu dijelaskan secara detail.

3. Penetapan landasan hukum / kebijakan dan masalah pembiayaan serta yang berkaitan dengan kepemilikan tanah seperti danau, telaga dan waduk terkadang cukup kompleks, mengingat tanah, danau dan waduk serta lingkungannya terkait dengan berbagai aspek peraturan lingkungan terutama penguasaan lahan. tanah. oleh negara, sehingga tingkat proseduralnya cukup tinggi dalam memanfaatkan tanah atau lahan untuk kepentingan pariwisata.

Kebijakan dalam pengembangan Pariwisata danau seringkali dikaitkan dengan berbagai fungsi seperti fungsi lingkungan, fungsi pengairan, fungsi kelistrikan, fungsi irigasi, fungsi perikanan dan seringkali fungsi pariwisata kadang-kadang tidak begitu menjadi perhatian.

Pembiayaan merupakan faktor esensial bagi pengembangan wisata danau, pembiayaan tidak hanya terkait dengan biaya operasional rutin 
untuk kepentingan pengelolaan tetapi analisis pembiayaan terkait dengan dampak yang ditimbulkan oleh kerusakan lingkungan, dibandingkan dengan hasil yang diperoleh, dalam hal apakah pembangunan kawasan berdampak pada ekonomi lingkungan atau sebaliknya. Lingkungan yang berkembang mengakibatkan menurunnya daya dukung ekonomi masyarakat. Mengawasi dan mengembangkan rencana pengembangan wisata danau agar tidak mengingkari asas kelestarian, misalnya dengan menetapkan standar produk, ramah lingkungan dan standar fasilitas yang sesuai dengan karakter alam dan potensi danau / danau.

Dengan memperhatikan kriteria, fungsi dan esensi tersebut di atas, pengembangan Pariwisata danau, membutuhkan beberapa pendekatan yang terintegrasi dengan mengembangkan sikap kepedulian lingkungan bagi siapapun yang akan mengelola Pariwisata danau.

Sektor pariwisata sebagai sektor pembangunan terus digalakkan oleh pemerintah dengan berbagai kebijakan guna meningkatkan pendapatan devisa negara. Namun kebijakan yang diambil oleh pemerintah dalam operasionalnya, khususnya di daerah yang memiliki potensi wisata, masih sering dihadapkan pada berbagai kendala. Promosi sektor pariwisata diarahkan untuk menjadi penghasil devisa negara. Karena pada dasarnya sektor pariwisata dapat memberikan kontribusi yang signifikan bagi pendapatan negara atau daerah, maka kontribusi penerimaan negara dari sektor pariwisata dapat terwujud jika ada sinergi antara pemerintah, swasta dan masyarakat yang secara bersama-sama memberikan pelayanan yang terbaik. untuk turis. Peran masyarakat dalam mendukung penyelenggaraan pariwisata sangat diperlukan, karena dengan melibatkan masyarakat pelaksana mendapatkan tenaga kerja yang murah namun tidak merugikan tenaga kerja, atau terjadi proses simbiosis mutualisme. Jika proses ini terjadi, maka pihak pelaksana secara tidak langsung akan meningkatkan kesejahteraan masyarakat.

Salah satu Pariwisata alam di daerah Sulawesi Utara khususnya di Kabupaten Minahasa adalah Danau Tondano yang hingga saat ini merupakan salah satu andalan di Kabupaten Minahasa. Berdasarkan dengan Peraturan Daerah Sulawesi Utara No.1 Tahun 2014 Pasal 55 Ayat 3 mengenai Kawasan Pariwisata Alam, di Danau Tondano sendiri diharapkan mengembangkan Pariwisata Danau dan untuk mengakomodasi semua kepentingan manusia dan kelestarian lingkungan. Oleh sebab itu, kajian mengenai Implementasi Pengelolaan Pariwisata Danau Tondano sangat dibutuhkan untuk memperoleh informasi yang akurat mengenai pengelolaan Pariwisata Danau Todano yang fungsional bagi masyarakat di Sekitaran bantaran Danau Tondano dan di Kabupaten Minahasa.

Sehubungan dengan hal tersebut, maka penelitian ini mengkaji bagiamana Implementasi pengelolaan Pariwisata di Bantaran Danau Tondano berdasarkan Peraturan Daerah Sulawesi Utara No.1 Tahun 2014 Pasal 55 Ayat 3 mengenai Kawasan Pariwisata Alam [3].

\subsection{Rumusan Masalah}

Berdasarkan latar belakang masalah di atas maka dirumuskan masalah sebagai berikut:

"Bagaimana Implementasi pengelolaan Pariwisata di Banataran Danau Tondano di Kabupaten Minahasa berdasarkan Peraturan Daerah Sulawesi Utara No.1 Tahun 2014 Pasal 55 Ayat 3 mengenai Kawasan Pariwisata Alam?"

\subsection{Tujuan Khusus}

Menganalisis Implementasi pengelolaan Pariwisata di Bantaran Danau Tondano Kabupaten Minahasa dan kontribusinya bagi masyarakat lokal serta faktor-faktor yang mempengaruhi pengelolaan Wisata di Danau Tondano Kabupaten Minahasa untuk kepentingan masyarakat lokal

\section{Metode Penelitian}

\subsection{Paradigma dan Jenis Penelitian}

Penelitian ini dilakukan dengan menggunakan paradigma naturalistik, yaitu paradigma yang melihat realitas sosial dalam latar alamiah, tanpa manipulasi pihak peneliti [4]. Penelitian ini dimaksudkan mendeskripsikan dan menganalisis pengelolaan Pariwisata di Bantaran Danau Tondano dengan berupaya mengungkapkan "bagaimana" pengelolaan pariwisata dalam upaya peningkatan taraf hidup masyarakat dan Faktor - faktor yang mempengaruhi Pengelolaan Pariwisata di Bantaran Danau Tondano. Dalam penelitian ini, peneliti berkeinginan untuk mendapatkan instrumen kebijakan pengelolaan Pariwisata di Bantaran Danau Tondano.

Dengan menggunakan paradigma naturalistik, Peneliti berkehendak untuk mengkaji realitas yang terdapat di lapangan mengenai pengelolaan Pariwisata di Bantaran Danau Tondano dengan mengkaji pengelolaan sebagaimana adanya. Pendekatan yang digunakan dalam penelitian ini adalah deskriptifkualitatif yang bertujuan untuk menemukan, menganalisis dan mendeskripsikan suatu kebijakan publik dalam proses pengelolaan Pariwisata di Bantaran Danau Tondano. Penelitian kualitatif menggunakan analisis data secara induktif. Data yang dikumpulkan adalah berupa kata-kata, gambar dan bukan angkaangka. 


\subsection{Fokus Penelitian}

Penelitian ini mengkaji tentang fungsionalisasi pengelolaan pada obyek wisata di Bantaran Danau Tondano bagi masyarakat sekitar. Diharapkan melalui penelitian ini dapat ditemukan bentuk pengelolaan obyek wisata yang berpihak pada masyarakat, sehingga masyarakat yang berada di sekitar obyek wisata mendapat manfaat dari pengelolaan wilayahnya. Namun penelitian ini lebih difokuskan pada:

1) Pengelolaan obyek wisata di Bantaran Danau Tondano:

a. Mekanisme pengelolaan obyek wisata.

b. Sistem koordinasi dan komunikasi pengelolaan obyek wisata.

c. Leading Sector dalam pengelolaan obyek wisata.

d. Dukungan Anggaran dalam pengelolaan obyek wisata.

2) Indikator pendukung dan penghambat dalam pengelolaan obyek wisata Bantaran Danau Tondano :

a. Indikator Pendukung pengelolaan obyek wisata di Bantaran Danau Tondano:

- Kebijakan

- Keputusan Pemerintah

- Kepentingan Umum/Masyarakat

- Sarana dan prasarana pengelolaan obyek wisata

- Kualitas SDM dalam pengelolaan obyek wisata

3) Model dalam pengelolaan obyek wisata di Bantaran Danau Tondano:

- Mekanisme Koordinasi dan kontribusi multisektor

- Pemanfaatan hasil pengelolaan obyek wisata

\subsection{Instrumen Penelitian}

Dalam penelitian kualitatif, instrumen utama adalah peneliti itu sendiri. Untuk itu peneliti berusaha mempelajari dengan cermat agar dalam merumuskan permasalahan dan fokus penelitian, memilih informan sebagai sumber data, mengumpulkan data, menafsirkan data, menganalisis data, sampai dengan penarikan kesimpulan dapat dilakukan dengan baik. Sehingga peneliti disebut sebagai instrumen kunci (key instrument), kemudian dibantu dengan catatan lapangan, notes, alat tulis, kamera foto, dan tape recorder .

\subsection{Teknik Pengumpulan Data}

Sebagaimana telah dikemukakan sebelumnya bahwa penelitian ini menggunakan teknik penelitian kebijakan publik sebagai metode utama dalam proses pengumpulan data lapangan. Data yang diperlukan akan dicari dengan menggunakan teknik pengamatan (observasi), wawancara dan dokumentasi.

\subsection{Teknik Analisis Data}

Proses analisis data yang diperoleh dari lapangan pada prinsipnya dilakukan bersama dengan pengumpulan data. Antara keduanya tidak dapat dipisahkan, sebab pada saat pengumpulan data secara tidak langsung terjadi proses analisa data. Proses selanjutnya adalah penyederhanaan data, agar supaya data dan informasi yang diperoleh dapat digunakan untuk menjelaskan permasalahan penelitian. Data yang ada dianalisis secara kualitatif deskritif (descriptive analysis).

Dalam pelaksanaan penelitian ini data yang diperoleh akan dianalisis dengan menggunakan teknik analisis data interaktif sebagaimana yang dikemukakan oleh Miles dan Huberman, berikut ini [5]:

1) Reduksi data

Data yang diperoleh di lapangan sebelum dianalisis dan dituangkan dalam laporan hasil penelitian terlebih dahulu akan direduksi, sehingga data yang dituangkan dalam laporan hasil penelitian tidak tumpang tindih dan dapat ditata secara logis.

2) Penyajian Data

Penyajian data atau display data adalah menggambarkan secara keseluruhan data penelitian yang telah direduksi. Data yang disajikan dalam penelitian sesuai dengan data di lapangan dan informasi yang diperoleh melalui informan. Data yang disajikan dalam bentuk laporan benar-benar dapat dipercaya dan dipertanggungjawabkan.

3) Penarikan kesimpulan/vertifikasi Pengambilan kesimpulan dalam penelitian kualitatif dimulai sejak awal artinya kesimpulan ini merupakan proses analisis untuk mendapatkan data yang kredibel.

\section{Hasil dan Pembahasan}

\subsection{Kawasan Pariwisata Alam di Bantaran Danau Tondano}

Dari hasil wawancara yang dilakukan terhadap Pemerintah Daerah Kabupaten Minahasa terhadap tiga istansi pemerintah yang terkait dengan kawasan wisata Danau Tondano yaitu Dinas Pariwisata, Dinas Kehutanan, dan Dinas Pendapatan Daerah dihasilkan sebagai berikut: 


\subsubsection{Dinas Pariwisata}

Hasil wawancara terhadap salah satu informan kunci Dinas Pariwisata menyatakan bahwa sejauh ini Implementasi Peraturan Daerah Sulawesi Utara No.1 Tahun 2014 Pasal 55 Ayat 3 di Danau Tondano belum maksimaldilakukan. Hal tersebut terjadi karena Kabupaten Minahasa memang pada dasarnyabukan merupakan daerah tujuan wisata, sehingga Pemerintah Daerah sejauh ini fokus pada program pembangunan daerah sehingga pengimplementasian Pariwisata di Bantaran Danau Tondano blum maksimal dilakukan. Selain itu, tingkat keinginan masyarakat Kabupaten Minahasa untuk berwisata masih sangat rendah, sehingga aktifitas wisata di kawasan Danau Tondano jarang dilakukan.

\subsubsection{Dinas Kehutanan}

Hasil wawancara yang dilakukan di Dinas Kehutanan Kabupaten Minahasa dihasilkan data bahwa sejauh ini telah banyak kegiatan-kegiatan baik berupa perlombaan maupun sosialisasi pembersihan kawasan Danau Tondano yang dilakukan atas kerjasama Pemerintah Daerah dan ikatan Pemuda Bantaran Danau Tondano. Pelibatan langsung Pemuda Bantaran Danau Tondano merupakan salahsatu bukti kepedulian masyarakat akan kelestarian Danau Tondano.

\subsubsection{Dinas Pendapatan Daerah}

Hasil wawancara yang dilakukan pada salah satu informan kunci Dinas Pendapatan Daerah menyatakan bahwa kendala yang selama ini mengakibatkan kawasan wisata Danau Tondano masih kurang pengunjung adalah tingkat kesulitan untuk menjangkau kawasan Danau Tondano, dimana aksesibilitas untuk mencapai kawasan wisata masih sangat minim, selain itu dia juga menyatakan bahwa selama ini banyak ditemukan warga Negara asing yang sengaja datang ke kawasan Danau Tondano untuk meneliti keanekaragaman hayati di dalamnya, namun sayangnya penelitian yang mereka lakukan terkadang tidak resmi atau illegal. Tidakhanya itu maraknya penjualan jenis ikan botini yang merupakan salah satu ikan endemik Danau Tondano yang dilakukan warga sekitar kawasan juga pernah ditemukan, hal ini terjadi karena kurangnya pemahaman masyarakat sekitar akan pentingnya menjaga kelestarian jenis ikan botini agar tidak punah.

\subsubsection{Balai Konservasi Sumber Daya Alam (BKSDA)}

Dari hasil wawancara yang telah dilakukan terhadap pihak Konservasi Sumber Daya Alam (KSDA) dihasilkan data bahwa untuk pengelolahan kawasan konservasi Danau Tondano belum maksimal dilakukan oleh pihak pengelola, dikarenakan dalam hal pengambilan kebijakan pihak-pihak terkait kurang memahami prosedur atau langkah-langkah yang harus mereka lalui berdasarkan status kawasan, sehingga dalam pengelolaannya masih ditemukan kendala-kendala yang dapat mempengaruhi Implementasi Peraturan Daerah Sulawesi Utara No. 1 Tahun 2014 Pasal 55 Ayat 3 di Bantaran Danau Tondanokedepannya.

\subsection{Sikap Kerjasama}

Berdasarkan hasil wawancara yang telah dilakukan pada tiga istansi terkait yaitu Dinas Pariwisata, Dinas Kehutanan, dan DinasPendapatan Daerah Kabupaten Minahasa menyatakan siap bekerjasama dengan pihak pengelola dan masyarakat untuk mengembangkan potensi wisata Danau Tondano.

\subsubsection{Balai Konservasi Sumber Daya Alam (BKSDA)}

Pada wawancara langsung yang dilakukan kepada Kepala Seksi Konservasi Sumber Daya Alam Malili Kabupaten Minahasa sebagai seksi pengelola kawasan Konservasi Danau Tondano dihasilkan data bahwa pihak pengelola siap bekerjasama dengan masyarakat dan Pemerintah Daerah untuk mengembangkan Pariwisata di Bantaran Danau Tondano namun perlu dilakukannya kesepakatan terlebih dahulu dalam hal pengambilan kebijakan dalam pengelolaan berdasaran ketentuan yang telah ditetapkan dalam undang-undang.

Faktor Internal : Kekuatan (Strenght)

1. Kawasan Danau Tondano memiliki potensi wisata.

Kawasan Danau Tondano sangat potensial untuk dikembangkan. Potensi tersebut meliputi kondisi bintang alam pada kawasan ini yang memiliki keindahan panorama alam, udara yang sejuk, dan kejernian air. Beberapa tempat di kawasan ini memiliki obyek daya tarik seperti potensi fisik berupa Kapal Nelayan Kecil, Eceng Gondok, Rumah Makan di Bantaran Danau Tondano, kedalaman danau, kejernian air danau, jenis ikan Nike, maupun budaya masyarakat sekitar Bantaran Danau Tondano atau mencari ikan di perairan Danau Tondano, bercocok tanam di sekeliling kawasan Danau Tondano. Akan tetapi potensi yang dimiliki harus ditangani dengan baik dan hati-hati khususnya dari sisi pemanfaatan secara lestari agar dampak dari kegiatan wisata ini tidak merusak kelestarian alam.

2. Lokasi yang mudah dijangkau.

$$
\text { Danau }
$$

Tondano adalah danau terluas Provinsi Sulawesi

Utara, Indonesia. Danau ini diapit oleh Pegunungan Lembean, Gunung Kaweng, Bukit Tampusu, dan Gunung 
Masarang. Danau ini dilingkari dengan jalan provinsi dan menghubungkan Kota Tondano, Kecamatan

Tondano

Timur, Kecamatan

Eris, Kecamatan

Kakas, Kecamatan

Remboken,

dan Kecamatan

Tondano

Selatan. Danau ini

merupakan danau penghasil ikan air tawar seperti ikan mujair, pior/kabos, payangka, betutu, wiko (udang kecil), nike, tawes, pongkor/ikan mas, lobster hitam,guramekupu-kupu,karper. Luas danau ini $4.278 \mathrm{ha} / 42,78 \mathrm{~km}^{3}$, dan terdapat pulau kecil bernama Likri (depan desa Tandengan satu kecamatan Eris) dan pulau babi, dinamakan pulau babi karna setiap kali ombak menerpa salah satu bagian di pulau itu, selalu terdengar suara seperti seekor babi yang berteriak.

Faktor Internal : Kelemahan (Weakness)

1. Akomodasi, Fasilitas, Sarana dan Prasarana yangkurang memadai.

Pengembangan Pariwisata di Bantaran Danau Tondano saat ini masih perlu memperhatikan hal-hal yang perlu dibenahi dari kawasan.Utamanya faktorfaktor yang dapat menunjang kegiatan Implementasi Peraturan Daerah Sulawesi Utara No.1 Tahun 2014 Pasal 55 Ayat 3 mengenai Kawasan Pariwisata Alam. Berdasarkan hasil observasi yang telah dilakukan, sampai saat ini yang tersedia pada kawasan Danau Tondano yaitu penginapan, rumah makan, MCK, perahu gayung (kayak), tempat sampah, dan warung-warung kecil yang telah disediakan. Kondisi tersebut menunjukkan bahwa faktor penunjang kegiatan berwisata pada kawasan inimasih minim.

2. Pemanfaatan potensi wisata alam belumoptimal.

Dalam hal pemanfaatan potensi wisata alam sejauh ini masih kurang optimaldisebabkankurangnya promosi dan informasi potensi pariwisata alam yang dimiliki sehingga keadaan wisata serta potensi-potensi yang dimiliki Danau Tondano masih kurang diketahui khalayak. Jika dibandingkan dengan Taman Wisata Alam Uluna, Benteng Moraya dll.

Faktor Eksternal : Peluang (Opportunities)

1. Masyarakat bersedia berpartisipasi dalam Implementasi Peraturan Daerah Sulawesi Utara No.1 Tahun 2014 Pasal 55 Ayat 3 mengenai Kawasan Pariwisata Alam.

Pelibatan masyarakat dalam pengelolaan kawasan ini akan menciptakan lapangan pekerjaan bagi masyarakat yang tentunya akan berdampak positif pada kesejahteraan masyarakat setempat. Pemikiran seperti inilah yang membuat timbulnya keinginan dari masyarakat untuk berpartisipasi serta ikut menjaga dan melestarikan kawasan. Berdasarkan hasil wawancara diperoleh data partisipasi masyarakat dalam pengimplementasian pariwisata yaitu sebanyak $72 \%$ bersedia dan $28 \%$ yang tidak bersedia.

Sebanyak 72 responden warga masyarakat sekitar bersedia berpartisipasi dan seluruh pedagang bersediah berpartisipasi. Ini merupakan salah satu modal utama dalam Implementasi Peraturan Daerah Sulawesi Utara No.1 Tahun 2014 Pasal 55 Ayat 3 mengenai Kawasan Pariwisata Alam, karena dengan berpartisipasinya masyarakat dan pedagang di sekitar kawasan, maka akan mempermudah dan mempercepat proses implementasi Pariwisata di Bantaran Danau Tondano. Selain bersedia untuk membantu dalam pelaksanaan kegiatan, partisipasi masyarakat juga dapat dilihat dari pengetahuan masyarakat tentang lokasilokasi obyek wisata yang berada di dalam kawasan, pada umumnya masyarakat yang sering melakukan aktifitas di dalam kawasan mengetahui tempat-tempat yang sangat potensial untuk dikembangkan. Sebanyak 51 orang responden warga masyarakat sekitar mengetahui lokasilokasiwisata yang ada dalam kawasan dan sisanya 49 orang responden tidak mengetahui lokasi- lokasi, sedangkan dari masyarakat yang berprofesi sebagai pedagang sebanyak 9 orang mengetahui lokasi-lokasi potensial dan selebihnya 12 orang tidak mengetahui. Tingginya tingkat pengetahuan masyarakat tentang kawasan Danau Tondano menjadi modal dasar untuk berpartisipasi karena informasi dari masyarakat sangat penting dalam pengelolaan peningkatan kualitas pariwisata di Danau Tondano.

2. Pihak Pemerintah Daerah dan pihak Pengelola Balai Konservasi Sumber Daya Alam (BKSDA) siap untuk bekerja dalam peningkatan Pariwisata di Bantaran Danau Tondano.

Berdasarkan hasil wawancara yang telah dilakukan, dalam hal prospek implementasi Pariwisata di Bantaran Danau Tondano, Pemerintah Daerah beserta pihak pengelola dari BKSDA bersedia dan siap bekerja demi tercaoainya tujuan dengan baik dan optimal. Dengan semangat dan tekad pemerintah daerah dengan pihak pengelola, ini merupakan modal dasar serta 
merupakan peluang mempermudah jalannya program kegiatan dalam meningkatkan Pariwisata di Bantaran Danau Tondano menjadi kawasan wisata yang lebih dikenal oleh khalayak.

Faktor Eksternal : Ancaman (Threats)

1. Belum singkronnya peraturan yang dikeluarkanPemerintah Daerah dan pihak pengelola.

Danau Tondano merupakan kawasan konservasi yang dibeberapa lokasinya telah dilakukan pembangunan, maupun masyarakat setempat. Tempat penyewaan alat renang dan perahu gayung (kayak) yang merupakan bangunan beton berada di tepi Danau Tondano dengan menggunakan lahan yang masih merupakan kawasan konservasi dan dianggap merusak kawasan serta kelestariannya. Hal ini terjadi karena pemberian kebijakan izin pembangunan tersebut tidak melalui pihak pengelola kawasan Danau Tondano yaitu BKSDA melainkan melalui Pemerintah Daerah. Ini merupakan ancaman kelestarian bagi Danau Tondano kedepan.

2. Pemanfaatan areal oleh masyarakat yang tidak sesuai peruntukannya.

Pada lokasi perairan Danau Tondano tepatnya di desa Tambeha dan area Sorowako Lama, terdapat beberapa rumah penduduk berdiri kokoh, berdasarkan penelitian yang telah dilakukan, masyarakat memanfaatkan daerah perairan Danau Tondano yang masih terbilang dangkal sebagai lahan pemukiman. Dampak yang ditimbulkan dengan dijadikannya daerah perairan Danau Tondano sebagai lokasi pemukiman, sampah-sampah berserakan, limbah manusia dimana-mana hingga mengotoriair Danau Tondano

3. Ketertarikan masyarakat terhadap kegiatan wisata alam masih rendah

Sejauh ini minat masyarakat Kabupaten Minahasa terhadap pentingnya berwisata masih rendah.Ini disebabkan karena sebagian besar penduduk setempat berprofesi sebagai petani, Pegawai Negeri Sipil dan lain-lain. Dalam kehidupan sehari- hari masyarakat banyak melakukan aktifitasnya di alam terbuka. Hal-hal tersebut merupakan dampak dari rendahnya kontribusi kunjungan wisata alam masyarakat setempat, sehingga masih perlu dilakukan sosialisasi dengan tujuan perlahan merubah pola pikir masyarakat agar lebih peduli terhadapdaerah wisata Danau Tondano yang selanjutnya meningkatkan minat berwisata.
Implementasi Peraturan Daerah Sulawesi Utara No.1 Tahun 2014 Pasal 55 Ayat 3 mengenai Kawasan Pariwisata Alam belum terlaksana dengan baik dilihat dari akomodasi, fasilitas, sarana, prasarana kurang memadai dan pemanfaatan potensi wisata alam yang belum optimal namun dalam pengembangannya Bantaran Danau Tondano sangat bisa dikembangkan dilihat dari potensi tersebut meliputi kondisi bintang alam pada kawasan ini yang memiliki keindahan panorama alam, udara yang sejuk, dan kejernian air. Beberapa tempat di kawasan ini memiliki obyek daya tarik seperti potensi fisik berupa Kapal Nelayan Kecil, Eceng Gondok, Rumah Makan di Bantaran Danau Tondano, kedalaman danau, kejernian air danau, jenis ikan nike yang menjadi ciri khas Danau Tondano atau mencari ikan di perairan Danau Tondano, bercocok tanam di sekeliling Bantaran Danau Tondano.

\section{Referensi}

[1] A. I, "Pariwisata Budaya Berkelanjutan, Refleksi dan Harapan di Tengah Perkembangan Global." Kajian Pariwisata Program Pascasarjana Universitas Udayana, 2003.

[2] S. Gumelar, "Konsep Pengembangan Kawasan Agrowisata." 2010.

[3] "Peraturan Daerah Sulawesi Utara No.1 Tahun 2014 Pasal 55 Ayat 3 mengenai Kawasan Pariwisata Alam.” 2014.

[4] I. Gunawan, "Metode Penelitian Kualitatif: Teori dan Praktik," Jakarta: Bumi Aksara. 2014.

[5] M. B. Miles and ;A Michael Huberman, "An Expanded Sourcebook Qualitative Data Analysis," Archives of Gynecology and Obstetrics. 1992.

\section{Kesimpulan}

